\title{
Getting the Dried Whey Protein Concentrate and Its Effect on Pan Bread Evaluation
}

\author{
Hanaa M. El-Azab"; Bosina M. Abd El-Latif *; Hamam E.M. Bahlol ${ }^{* *}$; Galal A.I. Ghazal ${ }^{* *}$ and Mahmoud H. M. Mahmoud ${ }^{* *}$ \\ * Food Technology Research Institute, Agricultural Research Center, Giza. \\ ** Food Technology Department, Faculty of Agriculture, Benha University.
}

\begin{abstract}
The aim of study is to obtain dried whey protein concentrate and to study the functional properties and physical, chemical properties. It was incorporated into pan bread made using different levels of dried whey protein concentrate. Pan bread samples were analyzed for sensory, physical and chemical attributes. The results revealed that sweet cheese whey contain $93.14 \%$ water, $4.85 \%$ lactose, $0.7 \%$ soluble protein, $0.11 \%$ fat and $0.9 \%$ ash contents. While, the produced dried whey protein concentrate contained $7.04 \%$ water $92.96 \%$ total solids, $10.47 \%$ lactose, $66.87 \%$ protein, $3.65 \%$ fat and $5.63 \%$ ash contents and contained higher levels of essential amino acids especially lysine, threonine and valine. Functional properties of dried whey protein concentrate were $4.8 \%, 2.2 \%$, $50 \%, 80 \%$ and $0.52 \mathrm{~g} / \mathrm{cm}^{3}$ for water absorption capacity, oil absorption capacity, foam capacity, foam stability and bulk density, respectively. Sensory, physical and chemical evaluation revealed that pan bread made using $20 \%$ dried whey protein concentrate had the best quality compared with control and other levels of dried whey protein concentrate.
\end{abstract}

Keywords: Dried whey protein concentrate - Pan bread - Physical and chemical properties - Sensory characteristics - Functional properties.

\section{Introduction}

Whey was a serious problem for dairy plants. It was not recycled to the extent it currently. Whey was removed along with sewage, which posed a threat to the ecosystem due to the organic compounds it contained (Wesolowska - Trojanowska and Targoński, 2014). In the case of cheese production, ten parts of milk give nine parts of whey and one part of cheese (Bylund, 2003).

The profitable solution of that environmental problem is to merge and insert waste whey into benefits industries such as food, chemical and pharmaceutical industries (Damodaran and Paraf, 1997). There are many ways to raise the economic values of waste dairy industry (permeate), production of bioactive compounds is one of important method that can be used in the food industry (Goulas $\boldsymbol{e t}$ al., 2007).

A tendency to use substitutes of ingredients in recipes of many products has been observed for several years in the food processing industry. It pertains to foods with reduced fat and sugar, or food products for vegetarians and people with lactose intolerance (Garcia-Serna et al., 2014). Whey and its preparations may serve as substitutes. According to many sources, their use can have a positive impact not only on the consumers' health, but also on the finances of many companies by reducing the costs of raw materials, and thus lowering production costs (Singh and Singh, 2012 and Božanić et al., 2014). Cost reduction is achieved by the use of whey preparations as partial or complete replacements of milk powder (De Wit, 2001), eggs, fat (Stoliar, 2009) and sucrose (Pernot-Barry, 2008).
There are two different types of whey: sweet whey and acid whey. Sweet whey is a by-product of ripened cheese production ( $\mathrm{pH}$ 5.8-6.6) whereas acid whey is obtained from cottage cheeses $(\mathrm{pH} 3.6-5.1)$ (Park and Haenlein, 2013).

The so-called whey proteins, which include $\beta$ lactoglobulin, $\alpha$-lactalbumin, lactoperoxidase, and lactoferrin, are the main source of whey healthpromoting properties (Kumar et al., 2008). The following peptides were identified in the $\beta$ lactoglobulin sequences: $\beta$-lactoferrin which influences the smooth muscles, $\beta$-lactotensin which exhibits hypocholesterolemic and anti-stress activities, and in the $\alpha$-lactalbumin sequences $\alpha$ lactoferrin which displays effects similar to that of morphine, namely blood pressure reduction (Chatterton et al., 2006).

Lactoferrin's ability to respond to a variety of physiological and environmental changes is a reason to consider it one of the key components in the host's first line of defense (Valenti and Antonini, 2005).

Precipitation methods are often used at the laboratory scale to obtain whey protein concentrates and produce peptides; however, the chemical composition and functionality of whey protein preparations and peptides are affected by the method used in the protein's concentration process. Chemical additives and factors, such as pressure, temperature, agitation rate and holding time, have been shown to affect solvent $\mathrm{pH}$, protein conformation and yield (Beolchini et al., 2004 and Casal et al., 2006). In particular, protein purity is critical for the biological activity of concentrated products. In addition, the biological properties of the concentrated products are difficult to standardize due to the complex nature of 
the bioactivities exerted by different whey proteins (Chollangi and Hossain, 2007).

Foams and emulsions are dispersed air/water and oil/water systems, respectively (Kilara and Vaghela, 2018). Protein function in foam properties as a surfactant by adsorbing at the freshly created air/water interface during bubble formation, and consequently lowers the interfacial tension and promotes bubble formation (Davis and Foegeding, 2007). Foaming performance of proteins is assessed by foaming capacity (FC) and foaming stability (FS). Higher FC implies greater incorporation of air bubbles, while FS describes the ability of proteins to form a strong and cohesive film around air bubbles (Patel and Kilara, 1990). Foams function as structuring materials in many food products and represent in the form of bread, ice cream and various baked goods (Ercelebi and Ibanoglu, 2009).

Emulsifying properties are usually described as emulsification capacity, which reflects the ability of the protein to rapidly adsorbs at the water/oil interface during the formation of the emulsion and preventing flocculation and coalescence (Webb et al., 2002). Emulsions can improve the texture, appearance and organoleptic attributes of many food products in general (Fachin and Viotto, 2005).

In addition, whey proteins contain a high level of essential amino acids; they are also considered a source of high-quality protein. In addition, they are characterized by a high content of calcium and other minerals, such as potassium and zinc. So, whey protein is a valuable additive to bakery products (Munaza et al., 2012).

Whey possesses potent antioxidant activity mainly contributed by cysteine-rich proteins that aid in the synthesis of glutathione (GSH), a potent intracellular antioxidant, also investigated as an anti-aging agent. Detoxifying property contributed by glutathione peroxidase, which is derived from selenium and cysteine, that converts lipid peroxides into less harmful hydroxy acids and $\alpha$-lactalbumin, which chelates heavy metals and reduces oxidative stress because of its iron-chelating properties (Tolson, 2004 and Onwulata and Huth, 2008).

Cereal-based foods have vital importance in human diet. Bread is a basic cereal food, which is an important source of carbohydrates, and as a consequence takes an important place in the recommended daily calorie intake (Dogan and Kücüköner, 1998).

The objective of present study was to evaluate the effect of incorporation of dried whey protein concentrate on sensory, physical, chemical, and texture of pan bread.

\section{Materials and Methods}

\section{Materials:}

Fresh sweet whey samples from both buffalo and cow's milk were obtained from cheddar cheese manufacture at Food Science Department, Cairo University.

Wheat flour ( $72 \%$ extraction) was obtained from the South Cairo flours Mills Company, Cairo, Egypt. Other materials used for the preparation of pan bread including active dry yeast, salt, corn oil and sugar were obtained from the local markets of Giza.

Methods:

Analytical methods:

Moisture, ash, crude fiber, fat and protein contents were determined according to the method described in A.O.A.C (2000). The total carbohydrate was calculated by differences.

The mineral elements of $\mathrm{K}, \mathrm{Na}, \mathrm{Mg}, \mathrm{Fe}$, and $\mathrm{Zn}$ in the digested samples were determined by atomic absorption spectrophotometry. Lactose was determined according to the method of Barnett and Tawab (1957).

\section{Preparation of whey protein:}

Dried whey proteins concentrate (DWPC) were obtained by thermal treatment of whey as follow: whey was acidified with lactic acid till $\mathrm{pH} 4.6$ then, the temperature was raised to $90^{\circ} \mathrm{C}$. After that whey was shocked cooled in cold water bath for about 10 min. Therefore, precipitated whey proteins were aggregated and filtered by clean mucilin cloth and the precipitated proteins were washed several times with distilled water then, dried at $40^{\circ} \mathrm{C}$ over night according to Mailliart and Ribadeau-Dumas (1988).

\section{Functional properties of concentrated dried whey protein: \\ Bulk density:}

The bulk density (BD) was determined by the method of Wang and Kinsella (1976).

\section{Water absorption capacity:}

The water absorption capacity (WAC) was estimated by the method of Lin $\boldsymbol{e t}$ al. (1974) with modification described by Quinn and Beuch (1975). Fat absorption capacity:

The fat absorption capacity (FAC) was measured by a modified method of Liu et al. (2012).

\section{Foaming expansion and stability}

Foaming expansion and stability were adapted according to the method of Patel et al. (1988).

Determination of total antioxidant activity:

The total antioxidant capacity was evaluated by the method of Prieto et al. (1999).

Procedure for making experimental pan bread:

The straight dough process for pan bread production was carried out according to the method of Kent-Jones and Amos (1967). Pan bread making involved mixing $300 \mathrm{~g}$ flour, instant active dry yeast (5 g), sugar (15 g), corn oil (15 g) and salt (3 g), the dried whey protein concentrate was replaced to pan bread flour at different levels of 5, 10, 15, 20, and $25 \%$. 
All ingredients were mixed and the resulted dough was let to rest for $30 \mathrm{~min}$ (first proofing), then divided into pieces (165 g), rolled and molded automatically in a molding machine. Each piece was placed in baking pans $(5 \times 9 \times 8)$, tightly greased to prevent the loaves from sticking. Pans were let to ferment for $60 \mathrm{~min}$ in a cabinet at $30^{\circ} \mathrm{C}$ and $85 \%$ relative humidity. The baking process was carried out in rotaroy electrical oven at $250^{\circ} \mathrm{C}$ for $25-30 \mathrm{~min}$. After baking; loaves were separated from baking pans and allowed to cool at room temperature for $1 \mathrm{hr}$ before weighing, measuring the volume and performing the organoleptic evaluation.

Blends of hard wheat flour with different substituted levels of dried whey protein concentrated used for the experimental production of pan bread:

\begin{tabular}{ccc}
\hline Blends & $\begin{array}{c}\text { Hard wheat flour }(\mathbf{H W F}) \\
(\boldsymbol{\%})\end{array}$ & $\begin{array}{c}\text { Dried whey protein concentrate } \\
\text { (DWPC) }(\boldsymbol{\%})\end{array}$ \\
\hline Control & 100 & 0 \\
$\mathbf{1}$ & 95 & 5 \\
$\mathbf{2}$ & 90 & 10 \\
$\mathbf{3}$ & 85 & 15 \\
$\mathbf{4}$ & 80 & 20 \\
$\mathbf{5}$ & 75 & 25 \\
\hline
\end{tabular}

Physical properties of pan bread:

The weight of bread loaves was determined after cooling for one hour. Bread loaf volume was measured by rape seed displacement method as described by A.A.C.C. (2000). Specific volume of bread was calculated by dividing volume of the loaves $\left(\mathrm{cm}^{3}\right)$ by their weights $(\mathrm{g})$.

Texture profile analysis of pan bread:

The texture profile analysis of pan bread conducted using CT3 Texture Analyzer (Version 2.1, 10000 Gram unit, Brookfield, Engineering Laboratories, Inc. USA). According to method 74-09 A.A.C.C. (2000).

\section{Sensory evaluation:}

The sensory evaluation of pan bread produced was done as described by Ali (2012).

\section{Statistical analysis:}

The data were presented as means \pm SD from three replicates. Data were subjected to one way ANOVA. The means of different treatments were compared using Duncan's multiple range tests at $\mathrm{p} \leq 0.05$. Statistical analyses were performed using SPSS statistical software (IBM SPSS Statistics, version 20) (Snedecor and Cochran, 1980).

\section{Results and Discussion}

\section{Chemical analysis of liquid cheese whey:}

Data in Table (1) shows the chemical composition of liquid cheese whey components. Results revealed that, liquid cheese whey contains about $93.14 \%$ water and the following nutrients from the original milk: lactose $(4.85 \%)$, soluble proteins $(0.70 \%)$, fat $(0.11 \%)$ and ash (0.90\%). Therefore, those chemical compositions represent $(6.86 \%)$ total solid and $\mathrm{pH}$ value was 5.0 for liquid whey. However, minerals such as $\mathrm{Mg} 1.278 \mathrm{mg}, \mathrm{Na} 4.813 \mathrm{ppm}, \mathrm{K} 0.772 \mathrm{ppm}$, Fe $0.0 \mathrm{ppm}$, and $\mathrm{Zn} 0.08 \mathrm{ppm}$. These results are in agreement with those results presented by Panesar $\boldsymbol{e t}$ al. (2007) and Smith (2012). They reported that the raw liquid whey is composed of naturally occurring macronutrients-ie water $93 \%$ protein $0.8 \%$, fat $0.3 \%$ lactose $4.8 \%$ and mineral- referred to as ash $0.5 \%$.

Also, from Table (1) chemical composition of dried whey protein concentrate were $7.04 \%$ of moisture and the following nutrients from the original milk: lactose, $(10.47 \%)$, crude proteins $(66.87 \%)$, fat $(3.65 \%)$ and ash $(5.63 \%)$. Therefore, those chemical compositions represent $92.96 \%$ total solids and $\mathrm{pH}$ value was 4.68 for dry whey protein concentrate. However, minerals such as $\mathrm{Mg} 7.76 \mathrm{mg}, \mathrm{Na} 131 \mathrm{ppm}$, $\mathrm{K} 81 \mathrm{ppm}$, Fe $0.0 \mathrm{ppm}$, and $\mathrm{Zn} 0.56 \mathrm{ppm}$. Whey contains numerous valuable micronutrients like, sodium, potassium, magnesium, citrate and phosphate that help to enhance the functionality of whey proteins (Zemel, 2004). Whey is also an excellent source of bioavallable calcium that improves bone health. The composition of whey salts expounded low sodium to potassium ratio that is essential for maintenance of blood pressure. Moreover, calcium from the whey is readily absorbed in the intestine, facilitated by the presence of lactose (Smithers, 2009). Also, Mg, K and $\mathrm{Na}$ represent good sources of these elements found in dry whey protein concentrate. The result are in agreement with the results presented by Onwulata et al. (2004) mentioned that dried whey protein concentrate contained moisture $5.3 \%$, crude protein $74.8 \%$, fat $2.3 \%$, ash $2.7 \%, \mathrm{pH}$ value $4.8 \%$ and carbohydrate $15.1 \%$ This could be attributed to the high protein and low fat and ash content in WPC (Table 1). It has been reported that the functional properties of whey products are related to the protein content and the composition of the product (Heino et al., 2007 and Ghanimah, 2018). 
Table 1. Physico-chemical composition of liquid and dried whey protein concentrate.

\begin{tabular}{lcc}
\hline Component & Liquid whey protein & Dry whey protein concentrate (DWPC) \\
\hline Moisture (\%) & 93.14 & 7.04 \\
Total solids $(\%)$ & 6.86 & 92.96 \\
Lactose $(\%)$ & 4.85 & 10.47 \\
Fat $(\%)$ & 0.11 & 3.65 \\
Protein $(\%)$ & 0.70 & 66.87 \\
Ash $(\%)$ & 0.90 & 5.63 \\
K (ppm) & 0.772 & 81 \\
Mg (ppm) & 1.276 & 7.76 \\
Na (ppm) & 4.813 & 131 \\
Fe (ppm) & Nil & Nil \\
Zn (ppm) & 0.08 & 0.56 \\
pH & 4.65 & 4.68 \\
\hline Total antioxidant & & $1200 \mathrm{ppm}$ \\
\hline
\end{tabular}

Antioxidant activity of dried whey protein concentrate:

Table (1) shows the antioxidant activities of dried whey protein concentrate products. Data is expressed as antioxidants activity equivalent to ascorbic acid (AAEAA). The values were $1200 \mathrm{ppm}$ for dried whey protein concentrate. The authors showed that low temperature- processed dried whey protein concentrate contains high levels of specific dipeptide (eg glutamyl cysteine) than promote the synthesis of glutathione, an important antioxidant involved in cellular protection and repair processes. Tseng et al. (2006) showed that dried whey protein concentrate product promotes gluthanion production which in turn enhances antioxidant activity in a pheochromocytoma cell line after acute ethanol exposure. Hsieh et al. (2015) mentioned the role of milk protein fraction as antioxidant against liquid peroxidation. This finding indicates that the role of milk proteins fractions namely whey protein against the rancidity of fatty foods.

Functional properties of dried whey protein concentrate (DWPC):

Functional properties of DWPC dried whey protein including water absorption capacity, oil absorption capacity, foam capacity, foam stability and bulk density are presented in Table (2). From the obtained results, it could be observed that DWPC was recorded 4.8 and $2.2 \mathrm{~g} / \mathrm{g}$ for water absorption capacity and oil absorption capacity, respectively. These results are in accordance with those obtained by Prinyawiwatkul et al. (1997). They mentioned that, protein water absorption capacity is a function of several parameters, including size, shape, steric factors and conformational characteristics hydrophilic- hydrophobic balance of amino acid, in the protein molecules as well as lipids, carbohydrates associated with protein. Carbohydrates contain hydrophilic parts, such as polar or charged side chains, which can enhance water absorption capacity.

From the results presented in the same table, it could be noticed that the foam capacity and stability of DWPC were recorded $50 \%$ and $80 \%$, respectively. The results suggested that the DWPC had a more flexible protein structure in aqueous solutions and interacted strongly at the air-water interface to form more stable foam as mentioned by Lawal et al. (2005). Patino et al. (2007) have been demonstrated that the foam stability increased with protein concentration in solution as can be seen in the current work.

Also, the obtained results indicated that bulk density of DWPC was $0.52 \mathrm{~g} / \mathrm{cm}^{3}$. High bulk densities are used as thickeners in food products.

Table 2. Functional properties of dried whey protein concentrate:

\begin{tabular}{lc}
\hline Functional properties & Dried whey protein concentrate (DWPC) \\
\hline Water absorption capacity (g/g) & 4.80 \\
Oil absorption capacity $(\mathbf{g} / \mathbf{g})$ & 2.20 \\
Foam capacity (FC) $(\%)$ & 50.00 \\
Foam stability (FS) $(\%)$ & 80.00 \\
Bulk density (BD) $\left(\mathbf{g} / \mathbf{c m}^{\mathbf{3}}\right)$ & 0.52 \\
\hline
\end{tabular}

Amino acids composition of dried whey protein concentrate:

Amino acids composition of DWPC is presented in Table (3). Levels of essential amino acids (EAAs) threonine, phenylalanine, valine, methionine, cysteine, isoleucine, leucine, lysine and tryptophan in raw WPC were 4.57, 2.87, 4.21, 1.80, 1.60, 3.41, 5.61, 6.83 and $1.3 \mathrm{~g} / 100 \mathrm{~g}$, respectively. It also appeared that lysine, threonine and valine were the first limiting amino acid in whey protein products, with values of $6.83,4.57$ and $4.21 \mathrm{~g} / 100 \mathrm{~g}$ DWPC, respectively. Hulmi et al. (2010) documented essential amino acids 
values in whey protein concentrate as $61,122,102,33$, $30,68,18$ and $59 \mathrm{mg} / \mathrm{g}$ for isoleucine, leucine, lysine, methionine, phenylalanine, threonine, tryptophan and valine, correspondingly. The results concerning amino acid profile of whey protein are in conformity with the findings of Etzel (2004), who noticed highest concentration of leucine as $118 \mathrm{mg} / \mathrm{g}$ whey protein isolate followed by lysine with mean value $95 \mathrm{mg} / \mathrm{g}$.

Table 3. Amino acid composition (g/100 g DWPC) of dried whey protein concentrated.

\begin{tabular}{lc}
\hline Amino acid & Dried whey protein concentrate \\
\hline Essential amino acids (EAA): & \\
\hline Isoleucine & 3.41 \\
Leucine & 5.61 \\
Lysine & 6.83 \\
Methionine & 1.80 \\
Cystine & 1.69 \\
Phenylalanine & 2.87 \\
Tyrosine & 1.31 \\
Threonine & 4.57 \\
Valine & 4.21 \\
Total essential amino acids & 32.30 \\
\hline Non-essential amino acids (NEAA): & \\
\hline Alanine & 2.75 \\
Arginine & 1.65 \\
Aspartic acid & 5.11 \\
Glutamic acid & 12.67 \\
Glycine & 1.49 \\
Proline & 5.38 \\
Serine & 2.76 \\
Histidine & 1.71 \\
Total non-essential amino acid & 33.52 \\
\hline Total amino acids & $\mathbf{6 5 : 8 2}$ \\
\hline
\end{tabular}

Chemical composition of pan bread made using concentrated dried whey protein concentrate:

As shown in Table (4) the moisture content of pan bread made using dried whey protein concentrate increase from $28.48 \%$ of control treatment to $39.83 \%$ of sample No. 4 which contained 20\% DWPC. There is a significant difference $(p \geq 0.05)$ in moisture content was found in all samples. The increase in moisture content with increasing the level of dried whey protein concentrate may be due to more bound water in the system. These results are in accordance with Gallagher et al. (2005). They reported that biscuits with dried whey protein concentrate were higher in moisture content compared with control sample.

Protein content in pan bread also increased significantly from 11.80 to $13.53 \%$ with increasing the levels of DWPC. The highest value for protein content $(13.53 \%)$ was observed in pan bread made using $(20 \%$ DWPC) compared with the lowest value (11.80\%) for control sample. Results also revealed that the protein content in all samples was different significantly. Similar results was observed by Munaza et al. (2012) they found that there was linear increase in protein content in the biscuit samples with increase in level of dried whey protein concentrate.
Fat content of pan bread was increased significantly from 4.69 to $6.46 \%$. The highest value of fat $(6.46 \%)$ was observed in sample No. 4 , while the lowest value $(4.69 \%)$ was observed in control sample. These results are in accordance with ash content of pan bread which increased significantly from 1.74 to $2.81 \%$. The highest value of ash content $(2.81 \%)$ was reported in sample No. 4 followed by sample No. 3 $(2.71 \%)$ and sample No. $2(2.14 \%)$, while the lowest value for ash $(1.74 \%)$ was observed in control sample. These results are in accordance with Gallagher $\boldsymbol{e t}$ al. (2005). They found that the increase in ash content in biscuits enriched with dried whey protein concentrate.

Fiber content of pan bread decreased significantly from 1.95 to $0.82 \%$. The maximum fiber content of $1.95 \%$ was observed in control sample followed by sample No. 1 (1.26\%), sample No. 2 (1.00\%) however, sample No. 4 showed the lowest fiber content of $0.82 \%$. These results are in accordance with Gayas et al. (2012) they reported that the decrease in fiber content in biscuits fortified with dried whey protein concentrate.

Finally, the available carbohydrates content of all pan bread were decreased significantly from 79.82 in control sample to $76.38 \%$ in sample No. 4 which contained $20 \%$ DWPC. 
Table 4. Chemical composition of pan bread made using different levels of dried whey protein concentrate $(\mathrm{g} / 100 \mathrm{~g})$.

\begin{tabular}{|c|c|c|c|c|c|c|c|}
\hline Sample & $\begin{array}{c}\text { Pan bread } \\
\text { blends } \\
\text { HWF+DWPC }\end{array}$ & Moisture & $\begin{array}{c}\text { Crude } \\
\text { protein* }\end{array}$ & $\begin{array}{c}\text { Ether } \\
\text { extract* }\end{array}$ & Ash* & $\begin{array}{l}\text { Crude } \\
\text { fiber* }\end{array}$ & $\begin{array}{c}\text { Available } \\
\text { carbohydrate*@ }\end{array}$ \\
\hline Control & $100+0$ & $\begin{array}{l}28.48 \\
\pm 0.73^{c}\end{array}$ & $\begin{array}{c}11.80 \\
\pm 0.55^{b c}\end{array}$ & $\begin{array}{c}4.69 \\
\pm 0.32^{c}\end{array}$ & $\begin{array}{c}1.74 \\
\pm 0.03^{\mathrm{c}}\end{array}$ & $\begin{array}{c}1.95 \\
\pm 0.16^{a}\end{array}$ & $\begin{array}{r}79.82 \\
\pm 0.85^{a}\end{array}$ \\
\hline 1 & $95+5$ & $\begin{array}{c}32.91 \\
\pm 1.90^{b}\end{array}$ & $\begin{array}{c}12.02 \\
\pm 0.18^{c}\end{array}$ & $\begin{array}{c}5.54 \\
\pm 0.74^{\mathrm{c}}\end{array}$ & $\begin{array}{c}1.86 \\
\pm 0.06\end{array}$ & $\begin{array}{c}1.26 \\
\pm 0.3^{b}\end{array}$ & $\begin{array}{r}79.32 \\
\pm 0.62^{\mathrm{a}}\end{array}$ \\
\hline 2 & $90+10$ & $\begin{array}{c}33.66 \\
\pm 0.59^{b}\end{array}$ & $\begin{array}{c}12.22 \\
\pm 0.18^{b}\end{array}$ & $\begin{array}{c}5.88 \\
\pm 0.26 \\
\text { bc }\end{array}$ & $\begin{array}{c}2.14 \\
\pm 0.10^{b}\end{array}$ & $\begin{array}{c}1.00 \\
\pm 0.13 \\
\text { bc }\end{array}$ & $\begin{array}{c}78.76 \\
\pm 0.70^{b}\end{array}$ \\
\hline 3 & $85+15$ & $\begin{array}{c}38.48 \\
\pm 0.34^{\mathrm{a}}\end{array}$ & $\begin{array}{c}13.04 \\
\pm 0.15^{\mathrm{a}}\end{array}$ & $\begin{array}{c}6.08 \\
\pm 0.26^{b}\end{array}$ & $\begin{array}{c}2.71 \\
\pm 0.12^{\mathrm{a}}\end{array}$ & $\begin{array}{c}0.91 \\
\pm 0.4^{\mathfrak{c}}\end{array}$ & $\begin{array}{l}77.26 \\
\pm 0.24^{\mathrm{c}}\end{array}$ \\
\hline 4 & $80+20$ & $\begin{array}{c}39.83 \\
\pm 0.23^{a}\end{array}$ & $\begin{array}{c}13.53 \\
\pm 0.13 \\
\end{array}$ & $\begin{array}{c}6.46 \\
\pm 0.24^{\mathrm{a}}\end{array}$ & $\begin{array}{c}2.81 \\
\pm 0.05^{a}\end{array}$ & $\begin{array}{c}0.82 \\
\pm 0.03^{\mathbf{c}}\end{array}$ & $\begin{array}{c}76.38 \\
\pm 0.32^{d}\end{array}$ \\
\hline
\end{tabular}

*: On dry weight basis.

@: Calculated by difference

$\mathrm{a}, \mathrm{b} \ldots$. There is no significant difference $(\mathrm{P}>0.05)$ between any two means, within the same column have the same superscript letter.

Physical properties of pan bread made using dried whey protein concentrate:

Physical properties i.e. weight, volume and specific volume of pan bread made using different levels of dried whey protein concentrate are shown in Table (5). These results declared that, the effect of adding DWPC at different levels to wheat flour (72\% ext.) was increase the volume and specific volume gradually with increasing the level of addition as compared to their corresponding control sample. The increase in volume of the prepared pan bread experimental samples could be attributed to the added
DWPC and may be due to the interaction between the protein and pan bread ingredients, especially the interaction between water and fat phases during pan bread making which caused increase in water retention in pan bread samples after baking. Dried whey protein concentrate gelation will increase the viscosity and also will give strength to the expanding cells of the dough; as a result, gas retention during baking improves and obtaining better specific volume (Marco and Rosell, 2008)

Table 5.Physical properties of pan bread made using dried whey protein concentrate.

\begin{tabular}{|c|c|c|c|c|}
\hline Sample & $\begin{array}{c}\text { Pan bread made from } \\
\text { HWF+DWPC }\end{array}$ & Volume $\left(\mathrm{cm}^{3}\right)$ & Weight (g) & $\begin{array}{l}\text { Specific volume } \\
\mathrm{cm}^{3} / \mathrm{g}\end{array}$ \\
\hline Control & $100+0$ & $496.67 \pm 8.82^{c}$ & $142.33 \pm 12.55^{\mathrm{a}}$ & $3.49 \pm 0.24^{b}$ \\
\hline 1 & $95+5$ & $553.33 \pm 8.82^{b}$ & $154.33 \pm 10.27^{\mathrm{a}}$ & $3.59 \pm 0.22^{b}$ \\
\hline 2 & $90+10$ & $576.67 \pm 26.03^{b}$ & $158.00 \pm 1.00^{\mathrm{a}}$ & $3.65 \pm 0.15^{\mathrm{ab}}$ \\
\hline 3 & $85+15$ & $601.67 \pm 36.55^{b}$ & $162.33 \pm 0.88^{a}$ & $3.71 \pm 0.17^{\mathrm{ab}}$ \\
\hline 4 & $80+20$ & $686.67 \pm 6.67^{a}$ & $166.67 \pm 2.96^{a}$ & $4.12 \pm 0.01^{\mathrm{a}}$ \\
\hline
\end{tabular}

$\mathrm{a}, \mathrm{b} \ldots . .$. : There is no significant difference $(\mathrm{P}>0.05)$ between any two means, within the same column have the same superscript letter

Texture Profile of pan bread made using different levels of dried whey protein concentrate during storage period:

Data illustrated in Table (6) show the effect of adding dried whey protein concentrate on hardness measurements of produced pan bread during storage time for $72 \mathrm{hr}$ at room temperature when comparing with control sample. The results indicated that the increasing addition levels of dried whey protein concentrate up to $20 \%$, the hardness values were decreased more than control. For instance, at 'zero time' hardness values for control sample were 13.50 however for the samples with DWPC were 13.43, 13.40 and 16.90 for 5,10 and $15 \%$, respectively, while the lowest hardness value for sample No. 2. During storage period time results showed that hardness values for control sample was increased more than all treatments of DWPC.
Cohesiveness as strength of the internal bonds making up the body of the product (Scheuer et al., 2014) From the results in Table (6) it could be shown the effect of adding dried whey protein concentrate to pan bread on the cohesiveness values which revealed an increasing in cohesiveness values correlated with increasing addition levels of DWPC during storage period when compared with control sample, while during storage time there was a shrinkage of cohesiveness for all treatments but less than control sample.

The gumminess and chewiness are the most indicative characteristic of fresh bread which is acceptable for consumers. As less gumminess and chewiness, the more freshness and staling retard, and vice versa. From Table (6) data showed the effect of increasing addition levels of DWPC during storage period on gumminess and chewiness values of produced pan bread, which revealed a decrease in both 
gumminess and chewiness values was more than control sample, while during storage time there was an increasing for both gumminess and chewiness values for all treatment. Gumminess and chewiness, are highly depending on hardness rather than cohesiveness or springiness values.

Table 6. Texture properties of pan bread made using dried whey protein concentrate.

\begin{tabular}{|c|c|c|c|c|}
\hline \multirow{2}{*}{ Substitution (\%) } & \multicolumn{4}{|c|}{ Storage period (hr) } \\
\hline & $\mathbf{0}$ & 24 & 48 & 72 \\
\hline \multicolumn{5}{|c|}{ Hardness } \\
\hline Control (0) & $13.50^{\mathrm{aB}}$ & $16.04^{\mathrm{aAB}}$ & $17.86^{\mathrm{Aa}}$ & $24.63^{\mathrm{bA}}$ \\
\hline 5 & $14.43^{\mathrm{aB}}$ & $19.08^{\mathrm{aB}}$ & $21.63^{\mathrm{Aab}}$ & $27.55^{\mathrm{bAB}}$ \\
\hline 10 & $14.48^{\mathrm{aB}}$ & $19.46^{\mathrm{aAB}}$ & $24.22^{\mathrm{Ab}}$ & $29.23^{\mathrm{bAB}}$ \\
\hline 15 & $16.90^{\mathrm{aB}}$ & $24.81^{\mathrm{aB}}$ & $27.48^{\mathrm{Aab}}$ & $41.31^{\mathrm{aA}}$ \\
\hline 20 & $17.52^{\mathrm{aB}}$ & $26.29^{\mathrm{aA}}$ & $28.87^{\mathrm{Ab}}$ & $44.98^{\mathrm{aA}}$ \\
\hline \multicolumn{5}{|c|}{ Cohesiveness } \\
\hline Control (0) & $0.78^{\mathrm{aA}}$ & $0.57^{\mathrm{aA}}$ & $0.40^{\mathrm{Ab}}$ & $0.38^{\mathrm{abB}}$ \\
\hline 5 & $0.73^{\mathrm{abA}}$ & $0.44^{\mathrm{bB}}$ & $0.38^{\mathrm{Ab}}$ & $0.35^{\mathrm{bB}}$ \\
\hline 10 & $0.68^{\mathrm{abcA}}$ & $0.43^{\mathrm{bB}}$ & $0.36^{\mathrm{Ac}}$ & $0.33^{\mathrm{bB}}$ \\
\hline 15 & $0.64^{\mathrm{bcA}}$ & $0.41^{\mathrm{bB}}$ & $0.36^{\mathrm{Ab}}$ & $0.30^{\mathrm{aB}}$ \\
\hline 20 & $0.61^{\mathrm{cA}}$ & $0.40^{\mathrm{bBC}}$ & $0.35^{\mathrm{Ab}}$ & $0.28^{\mathrm{bC}}$ \\
\hline \multicolumn{5}{|c|}{ Gumminess } \\
\hline Control (0) & $11.10^{\mathrm{aB}}$ & $9.28^{\mathrm{aB}}$ & $7.90^{\mathrm{aA}}$ & $5.55^{\mathrm{bB}}$ \\
\hline 5 & $11.12^{\mathrm{aA}}$ & $9.54^{\mathrm{Ab}}$ & $8.68^{\mathrm{Aa}}$ & $7.89^{\mathrm{aAB}}$ \\
\hline 10 & $11.60^{\mathrm{aB}}$ & $9.59^{\mathrm{aB}}$ & $8.99^{\mathrm{Ab}}$ & $8.18^{\mathrm{bA}}$ \\
\hline 15 & $11.81^{\mathrm{aB}}$ & $10.92^{\mathrm{aB}}$ & $9.03^{\mathrm{Ab}}$ & $8.89^{\mathrm{aA}}$ \\
\hline 20 & $12.61^{\mathrm{aA}}$ & $11.91^{\mathrm{aA}}$ & $10.30^{\mathrm{Aab}}$ & $9.50^{\mathrm{bB}}$ \\
\hline \multicolumn{5}{|c|}{ Chewiness } \\
\hline Control (0) & $85.60^{\mathrm{aA}}$ & $77.10^{\mathrm{aA}}$ & $56.70^{\mathrm{aA}}$ & $53.00^{\mathrm{aB}}$ \\
\hline 5 & $72.30^{\mathrm{aB}}$ & $62.90^{\mathrm{aB}}$ & $51.00^{\mathrm{aAB}}$ & $45.60^{\mathrm{bA}}$ \\
\hline 10 & $68.80^{\mathrm{aA}}$ & $55.40^{\mathrm{aAB}}$ & $51.00^{\mathrm{aB}}$ & $43.70^{\mathrm{bB}}$ \\
\hline 15 & $65.70^{\mathrm{aA}}$ & $53.90^{\mathrm{aA}}$ & $47.40^{\mathrm{aA}}$ & $40.40^{\mathrm{aA}}$ \\
\hline 20 & $47.80^{\mathrm{aB}}$ & $52.70^{\mathrm{aB}}$ & $44.00^{\mathrm{aA}}$ & $39.10^{\mathrm{bA}}$ \\
\hline \multicolumn{5}{|c|}{ Adhesivenes } \\
\hline Control (0) & $0.40^{\mathrm{aA}}$ & $0.20^{\mathrm{abAB}}$ & $0.10^{\mathrm{aB}}$ & $0.10^{\mathrm{aA}}$ \\
\hline 5 & $0.40^{\mathrm{aA}}$ & $0.20^{\mathrm{abAB}}$ & $0.10^{\mathrm{aA}}$ & $0.10^{\mathrm{aA}}$ \\
\hline 10 & $0.40^{\mathrm{aA}}$ & $0.20^{\mathrm{abAB}}$ & $0.10^{\mathrm{aB}}$ & $0.00^{\mathrm{bB}}$ \\
\hline 15 & $0.30^{\mathrm{abA}}$ & $0.10^{\mathrm{bA}}$ & $0.10^{\mathrm{aB}}$ & $0.00^{\mathrm{bB}}$ \\
\hline 20 & $0.20^{\mathrm{abc} A B}$ & $0.00^{\mathrm{bA}}$ & $0.10^{\mathrm{aA}}$ & $0.00^{\mathrm{bB}}$ \\
\hline \multicolumn{5}{|c|}{ Springiness } \\
\hline Control (0) & $5.07^{\mathrm{aBC}}$ & $4.98^{\mathrm{aB}}$ & $3.73^{\mathrm{cB}}$ & $2.82^{\mathrm{dB}}$ \\
\hline 5 & $5.92^{\mathrm{aA}}$ & $5.27^{\mathrm{aA}}$ & $4.46^{\mathrm{bcB}}$ & $3.92^{\mathrm{aA}}$ \\
\hline 10 & $6.19^{\mathrm{aA}}$ & $5.76^{\mathrm{abB}}$ & $5.44^{\mathrm{aA}}$ & $4.78^{\mathrm{cC}}$ \\
\hline 15 & $6.23^{\mathrm{aB}}$ & $5.81^{\mathrm{abA}}$ & $5.56^{\mathrm{aAB}}$ & $5.22^{\mathrm{bcA}}$ \\
\hline 20 & $6.79^{\mathrm{aA}}$ & $6.76^{\mathrm{abA}}$ & $6.47^{\mathrm{aAB}}$ & $5.64^{\mathrm{aB}}$ \\
\hline \multicolumn{5}{|c|}{ Resilience } \\
\hline Control (0) & $0.28^{\mathrm{dA}}$ & $0.17^{\mathrm{aC}}$ & $0.15^{\mathrm{aB}}$ & $0.14^{\mathrm{aC}}$ \\
\hline 5 & $0.32^{\text {cdA }}$ & $0.18^{\mathrm{aB}}$ & $0.16^{\mathrm{aB}}$ & $0.15^{\mathrm{bC}}$ \\
\hline 10 & $0.35^{\mathrm{bcA}}$ & $0.21^{\mathrm{aB}}$ & $0.16^{\mathrm{aC}}$ & $0.15^{\mathrm{bB}}$ \\
\hline 15 & $0.39^{\mathrm{abA}}$ & $0.21^{\mathrm{aB}}$ & $0.17^{\mathrm{aBC}}$ & $0.15^{\mathrm{bC}}$ \\
\hline 20 & $0.43^{\mathrm{aA}}$ & $0.23^{\mathrm{aB}}$ & $0.21^{\mathrm{aB}}$ & $0.17^{\mathrm{abB}}$ \\
\hline
\end{tabular}

$\mathrm{a}, \mathrm{b} \ldots \ldots$. There is no significant difference $(\mathrm{P}>0.05)$ between any two means, within the same column have the same superscript letter

A, B .....: There is no significant difference $(\mathrm{P}>0.05)$ between any two means, within the same row have the same superscript letter.

Textural properties, such as resilience usually decreased during storage time with increasing staling and deformation. Resilience increased linearly with moisture content (Stampfli and Nersten, 1995). From previous context and results illustrated in Table (6) it was obvious that during storage period resilience values were decreased for all treatments parallel with losing moisture and staling, however control sample was possessed the lowest resilience values when compared with all treatments during storage time, and instance resilience for pan bread made using $10 \%$ DWPC were $0.35,0.21,0.16$, and 0.15 . While, it was 
$0.28,0.17,015$ and 0.14 for control sample at 0,24 , 48, and $72 \mathrm{hr}$. These results are in harmony with Goesaert et al. (2009) who reported that bread quality decreases during storage period because bread crumb and crust get firmed and lose resilience. These results are in agreement with those obtained by Ribotta $\boldsymbol{e t}$ al. (2005). The adhesiveness and resilience initially decreased and then increased with increasing the level of WP from 0 to $30 \%$. The results above again suggested that when WP was at high concentration (higher than gluten content), the heat induced WP gel became dominant phase and significantly affected quality characteristics of the bread Table (6), at storage time when compared with control, with increasing addition levels.

These results indicated that the addition of concentrated dried whey protein concentrate to the formulations contributed to enhance textural properties, except for adhesiveness and cohesiveness, which is attributed to its high-water retention capacity and gelling properties. This is in agreement with the results presented by Antunes et al. (2003) they reported that, $\beta$-lactoglobulin is the main gelling agent due to the presence of free sulfhydryl groups. Formulations supplemented with concentrated dried whey protein showed greater elasticity. This parameter is strongly related to the formation of intermolecular disulfide bonds (Shimada and Cheftel, 1989).

Sensory evaluation of pan bread made using different levels of dried whey protein concentrate:

The results for the sensory evaluation of pan bread made using different levels of dried whey protein concentrate are given in Table (7) and it is revealed that the DWPC was different impact on sensory attributes like color, texture, taste, flavor, and overall acceptability. The results indicated that the mean score for the color had been increased from11.4 for control treatment to 13.9 for pan bread made using the level of (20\% DWPC). Mean score for texture had been increased significantly from 11.9 for control to 13.7 with increasing the level of DWPC to $20 \%$ (sample No. 4).
The quality score in response to taste of the pan bread depicted that the highest significant score of 18.0 was shown in blend 4 sample. While the lowest significant mean score of 15.1 was observed in control sample., Results pertaining to flavor of pan bread are presented in the same table, and revealed that, the highest significant score for odor 18.1 was observed in sample No. 4. While, the lowest sgnificant mean score of 15.7 was observed in control sample Data in the same table indicated that the 15 and $20 \%$ levels substitution of DWPC were increased the scores of sensory properties of corresponding all samples compared to control. Overall acceptability was determined on the basis of quality scores obtained from the evaluation of color, texture, taste and flavor of the pan bread. The mean score regarding overall acceptability of pan bread revealed that sample No. 4 have the maximum score (90.7) of overall acceptability, while, the sample No. 5 have the minimum score compared to control sample (45.01). The decrease in overall acceptability was due to the decrease in quality score in response to texture, taste and flavor. Shim and Mulvaney (2001) reported that in response to the addition of WPC, significantly increased, indicating that the addition of WPC reduced the thermal stability of the starch in dough. The addition of WPC destroyed the continuous gluten network structure and subsequently weakening its protective effect on starch subjected to amylase. As the substitution level of WPC increased. The results obtained are in close with Singh $\boldsymbol{e t}$ al. (1993) they reported similar results regarding overall acceptability score of sensory evaluation. Addition of whey and dried whey protein concentrate improved sensory quality of different baked products and even various traditional foods such as gulabjamun (Vani and Jayaprakasha, 2004) and finger millet (Tripathy et al., 2003).

Improvement of sensory quality of bread by supplementation of other forms of whey and whey protein products has been extensively reported (Vetter, 1984; Abdel-Aal et al., 1999; Mannie and Asp, 1999 and Gallagher et al., 2003).

Table 7. Sensory evaluation of pan bread made using dried whey protein concentrate.

\begin{tabular}{cccccccc}
\hline $\begin{array}{c}\text { Pan bread blends } \\
\text { HWF + DWPC }\end{array}$ & $\begin{array}{c}\text { Crust } \\
\text { appearances } \\
(\mathbf{1 5})\end{array}$ & $\begin{array}{c}\text { Crust } \\
\text { color } \\
(\mathbf{1 5})\end{array}$ & $\begin{array}{c}\text { Crumb } \\
\text { color } \\
(\mathbf{1 5})\end{array}$ & $\begin{array}{c}\text { Texture } \\
\mathbf{( 1 5 )}\end{array}$ & $\begin{array}{c}\text { Taste } \\
\mathbf{( 2 0 )}\end{array}$ & $\begin{array}{c}\text { Odor } \\
(\mathbf{2 0})\end{array}$ & $\begin{array}{c}\text { Overall } \\
\text { acceptability } \\
(\mathbf{1 0 0})\end{array}$ \\
\hline Control 100+0 & $11.4^{\mathrm{c}}$ & $11.6^{\mathrm{c}}$ & $12.4^{\mathrm{b}}$ & $11.9^{\mathrm{c}}$ & $15.1^{\mathrm{d}}$ & $15.7^{\mathrm{c}}$ & $78.1^{\mathrm{c}}$ \\
$\mathbf{9 5}+\mathbf{5}$ & $12.3^{\mathrm{bc}}$ & $13.1^{\mathrm{a}}$ & $12.2^{\mathrm{b}}$ & $12.4^{\mathrm{b}}$ & $16.9^{\mathrm{bc}}$ & $17.0^{\mathrm{b}}$ & $83.9^{\mathrm{bc}}$ \\
$\mathbf{9 0}+\mathbf{1 0}$ & $12.8^{\mathrm{b}}$ & $12.0^{\mathrm{b}}$ & $13.0^{\mathrm{a}}$ & $12.1^{\mathrm{b}}$ & $16.4^{\mathrm{c}}$ & $17.1^{\mathrm{b}}$ & $83.4^{\mathrm{bc}}$ \\
$\mathbf{8 5}+\mathbf{1 5}$ & $12.6^{\mathrm{b}}$ & $12.9^{\mathrm{ab}}$ & $12.4^{\mathrm{b}}$ & $13.4^{\mathrm{a}}$ & $17.1^{\mathrm{b}}$ & $17.1^{\mathrm{b}}$ & $85.5^{\mathrm{ab}}$ \\
$\mathbf{8 0}+\mathbf{2 0}$ & $13.9^{\mathrm{a}}$ & $13.4^{\mathrm{a}}$ & $13.6^{\mathrm{a}}$ & $13.7^{\mathrm{a}}$ & $18.0^{\mathrm{a}}$ & $18.1^{\mathrm{a}}$ & $90.7^{\mathrm{a}}$ \\
$\mathbf{7 5}+\mathbf{2 5}$ & $7.07 \mathrm{~d}$ & $7.29 \mathrm{~d}$ & $6.87 \mathrm{c}$ & $7.21 \mathrm{~d}$ & $8.43 \mathrm{e}$ & $8.14 \mathrm{~d}$ & $45.01 \mathrm{~d}$ \\
\hline
\end{tabular}

$\mathrm{a}, \mathrm{b} \ldots$... There is no significant difference $(\mathrm{P}>0.05)$ between any two means, within the same column have the same superscript letter. 
Finally, from the obtained results, it could be concluded that the $20 \%$ dried whey protein concentrate supplemented pan bread samples were nutritionally rich and have the highest score in most of the sensory evaluation attributes.

\section{References}

A.A.C.C. 2000: Approved methods of American Association of Cereal Chemists. $10^{\text {th }}$ Ed., A.A.C.C. International, St. Paul, MN.

A.O.A.C. 2000: Official Methods of Analysis. Association of the Official Analytical Chemists. International $17^{\text {th }}$ Edition, Revision 1, 2002, Virginia, USA.

Abdel-Aal, E.S.M.; Hucl, P. and Sosulski, F.W. 1999. Optimizing the bread formulation for soft splet wheat. Cereal Food World, 44: 480-483

Ali, W.M. 2012. Studies on used some emulisifiers to improvement the quality of some bakery products. M.Sc. Thesis, Fac. Of Agric., Benha Univ.

Park, Y.W. and Haenlein, G.F.W. 2013. Whey and Whey Products, in: Milk and Dairy Products in Human Nutrition: Production, Composition and Health (eds.). John Wiley and Sons, Oxford, pp. 477-492.

Antunes, A.E.C.; Motta, E.M.P. and antunes, A.J. 2003. Perfil de textura e capacidade de retenção de água de géis ácidos de concentrado protéico de soro de leite. Ciência e Tecnologia de Alimentos, 23: 183-189.

Barnett, A.J. and Tawab, G. 1957. Rapid determination of lactose. J. Sci. Food Agric., 8: 438-440.

Beolchini, F.; Veglio, F. and Barba, D. 2004. Microfiltration of bovine and ovine milk for the reduction of microbial content in a tubular membrane: a preliminary investigation. Desalination. 161: 251-258.

Božanić, R.; Barukčić, I.; Jakopović, K.L. and Tratnik L. 2014. Possibilities of whey utilisation. Austin J. Nutri. Food Sci., 2: 1036-1042.

Bylund, G. 2003. Dairy Processing Handbook. Tetra Pak Processing Systems

Casal, E.; Montilla, A.; Moreno, F. J.; olano, A.;Corzo, N. J Dairy Sci. 2006, 89, 1384-1389.

Chatterton, D.E.W.; Smithers, G.; Roupas, P. and Brodkorb, A. 2006. Bioactivity of $\beta$-lactoglobulin and $\alpha$-lactalbumin-Technological implications for processing. Int. Dairy J., 16: 1229-1240

Chollangi, A. and Hossain, M. 2007. Seperation of proteins and lactose from dairy wastewater. Chem. Eng. Process.: Process Intesfication 46, 398-404.

Damodaran, S. and Paraf, A. 1997. Food Proteins and their Applications, Vol. 80. Marcel Dekker, New York.

Davis, J. and Foegeding, A. 2007. Comparisons of the foaming and interfacial properties of whey protein isolate and egg white proteins. 54: 200210.
De Wit, J.N. 2001. Lecturer's handbook on whey and whey products. European Whey Products Association. $1^{\text {st }}$ Ed. Brussels, Belgium.

Dogan, S.S. and Kücüköner, E. 1998. Utilization of dairy ingredients in bakery products. Gida 23: 4347.

Ercelebi, E. and Ibanoglu, E. 2009. Effects of ionic strength on the foaming properties of whey protein isolate and egg white in the presence of polysaccharides. J. Food Process Preserv. 33: 513526.

Etzel, M.R. 2004. Manufacture and use of dairy protein fractions. J. Nutr., 134: 996-1002.

Fachin, L. and Viotto, W.H. 2005. Effect of pH and heat treatment of cheese whey on solubility and emulsifying properties of whey protein concentrate produced by ultrafiltration. Int. Dairy J. 15: 325-332.

Garcia-Serna, E.; Martinez-Saez, N.; Mesias, M.; Morales, F.J. and del Castillo, M.D. 2014. Use of coffee Silver skin and Stevia to improve the formulation of biscuits. Pol. J. Food Nutr. Sci., 64: 243-251.

Gallagher, E.; Kenny, S. and Arendt, E.K. 2005. Impact of dairy protein powders on biscuit quality. European Food Research Technology, 221: 237-243.

Gallagher, E.; Gormley, T.R. and Arendt, E.K. 2003. Crust and crumb characteristics of gluten free breads. J Food Eng., 56: 153-16

Gayas, B.; Shukla, R.N. and Khan, B.M. 2012. Physico-chemical and sensory characteristics of carrot pomace powder enriched defatted soy flour fortified cookies. International Journal, 2(8): 1-5.

Ghanimah, M. 2018. Functional and technological aspects of whey powder and whey protein products. Int. J. Dairy Technol., 71: 454-459

Goesaert, H; Leman P; Bijttebier, A. and Delcour JA. 2009. Antifirming effects of starch degrading enzymes in bread crumb. Journal of Agri., and Food Chem., 57: 2346-2355

Goulas, A.; Tzortzis, G. and Gibson, G.R. 2007. Development of a process for the production and purification of $\alpha$ - and $\beta$-galactooligosaccharides from Bifidobacterium bifidum NCIMB 41171. International Dairy Journal, 17: 648-656.

Heino, A., Uusi-Rauva, J., Rantamaki, P. and Tossavainen, O. 2007. Functional properties of native and cheese whey protein concentrate powders. Int. J. Dairy Technol., 60: 277-285.

Hsieh, C.C.; Hernandez-Ledesma, B.; FernandezTome, S.; Weinborn, V. Barile, D. and Bell, J.M. 2015. Milk proteins, Peptides, and Oligosaccharides: Effects against the 21st Century Disorders BioMed Research International. Volume 2015, Article ID 146840, 16 pages http://dx.doi.org/10.1155/2015/146840

Hulmi, J.J., Lockwood C.M. and Stout, J.R. 2010. Effect of protein/essential amino acids and kresistance training on skeletal muscle 
hypertrophy: A case for whey protein. Nutr. Metabol., 7: 51-51.

Kent-Jones, D.W. and Amos, A.J. 1967. Modern cereal chemistry. Food Trade Press, 6: 501-504

Kilara, A. and Vaghela, M. 2018. Whey proteins. pp 30-55, In : Yada, R. (Ed.). Handbook of Food Proteins. Elsevier Ltd. https://doi.org/10.1016/ B978-1-84569-758-7.50003-4

Kumar, R.; Sangwan, R.B. and Mann, B. 2008. Separation and application of bioactive whey proteins. Technological Advances in the utilization of dairy by-products, $22^{\text {nd }}$ Short Course. Available at: [http://www. Dairyprocessingcaft.com /wpcontent/uploads/2012/05/ Byproducts-2008.pdf].

Lawal, O.; Adebowale, K.; Ogunsanwo, B.; Sosanwo, O. and Bankole, S. 2005. On the functional properties of globulin and albumin protein fractions and flours of African locust bean (Parkia biglobossa). Food Chem., 92: 681-691

Lin, M.J.Y.; Humbert, E.S. and Sosulki, F.W. 1974. Certain functional properties of sunflower meal product. J. Food Sci. 39: 368-370

Liu, J.; Ru, Q. and Ding, Y. 2012. Glycation a promising method for food protein modification: physicochemical properties and structure, a review. Food Res. Inter., 4(1): 170-183.

Mailliart, P. and Ribadeau-Dumas, B. 1988. Preparation of $\beta$-Lactoglobulin and $\beta$ Lactoglobulin free Proteins from whey retentate by $\mathrm{NaCl}$ salting out at low ph. J. Food Sci., 53: 743-752

Mannie, E. and Asp, E.H. 1999. Dairy ingredients for bread baking. Cereal Food World 44: 143-146.

Marco, C. and Rosell, C.M. 2008. Bread-making performance of protein enriched, gluten-free breads. European Food Research and Technology, 227: 1205-1213.

Munaza, B.; Prasad, S.G.M. and Gayas, B. 2012. Whey protein concentrate enriched biscuits. Int. J. Sci. Res. Publ., 2: 1-4.

Onwulata, C.I. and Huth, P.J. 2008. Whey proteins and peptides in human health. In: Whey processing, functionality and health benefits. Published by Wiley-Blackwell. IFT press. Lowa, USA, 285-309.

Onwulata, C.I.; Konstance, R.P. and tomasula, P.M. 2004. Minimizing variations in functionality of whey protein concentrates from different sources. J. Dairy Sci., 87: 749-756

Quinn, L. and Beuch, R. 1975. Functional property changes resulting from fungal fermentation of peanut flour. 40: 475- 478

Panesar, P.S.; Kennedy, J.F.; Gandhi, D.N. and Bunko, K. 2007. Bio-utilisation of whey for lactic acid production. Food Chem., 105(1): 1-14.

Patel, P.D.; Stripp, M.A. and Fry, C.J. 1988. Whipping test for the determination of foaming capacity of protein : A collaborative study. Inter. J. Food Sci. Technol., 23: 57-
Patel, M. and Kilara, A. 1990. Studies on whey protein concentrates.2. Foaming and emulsifying properties and their relationships with physicochemical properties. J. Dairy Sci., 73: 2731- 2740

Patino J.M.R. Conde J.M.; Linares, H.M.; Sánchez, C.C. and Pizones, V. 2007. Interfacial and foaming properties of enzyme-induced hydrolysis of sunflower protein isolate. Food Hydrocoll., 21(56): 782-793.

Pernot-Barry, A. 2008. Importance of whey ingredients in confectionery products. $5^{\text {th }}$ International Whey Conference, Paris. Available at:

[http://ewpa.euromilk.org/nc/publications.html?ci $\mathrm{d}=302 \& \mathrm{did}=2379 \&$ sechash=aebab0e0].

Prinyawiwatkul, W.; Beuchat, L.R.; McWatters, K.H. and Phillips, R.D. 1997. Functional properties of cowpea (Vigna unguiculata) flour as affected by soaking, boiling, and fungal fermentation. J. Agri. Food Chem., 45: 480-486.

Prieto, P.; Pineda, M. and Aguilar, M. 1999. Spectrophotometric quantitation of antioxidant capacity through the formation of a phosphomolybdenum complex: specific application to the determination of vitamin E. Analytical Biochem., 269(2): 337-41.

Ribotta, P.D.; Arnulphi, S.A.; Leon, A.E. and Anon, M.C. 2005. Effect of soybean addition on the rheological properties and breadmaking quality of wheat flour. Journal of the Science of Food and Agriculture, 85: 1889-1896.

Scheuer, P.M; Mattioni, B.; Barreto, P.L.M.; Montenegro, F.M; Gomes-Ruffi, C.R.; Biondi, S. and Francisco, A.D. 2014. Effects of fat replacement on properties of whole wheat bread. Brazilian Journal of Pharmaceutical Sciences, 50(4): 703-712.

Shimada, K. and Cheftel, J.C. 1989. Texture characteristics, protein solubility, and sulphydryl group/disulfide bond content of heat-induced gels of whey protein isolate. Journal of Agricultural and Food Chemistry, 36: 1018-1025.

Shim, J. and Mulvaney, S.J. 2001. Effect of heating temperature, $\mathrm{pH}$, concentration and starch/whey protein ratio on the viscoelastic properties of corn starch/whey protein mixed gels. Journal of the Science of Food and Agriculture, 81: 706-717.

Singh, A.K. and Singh, K. 2012. Utilization of whey for the production of instant energy beverage mby using response surface methodology. Advance J. Food Sci. Technol., 4: 103-111.

Singh, B.; Bajaj, M.; Kour, A.; Shama, S. and Sidhu, J. 1993. Studies on the development of high - protein biscuits from composite flour. Plant Food for Human Nutrition, 43: 181-189.

Smith, K. 2012. Current and Future Processing of Whey Ingredients. Wisconsin Center for Dairy 784 Research. Center for Dairy Research 
Smithers, G.W. 2009. Whey and whey proteins-From 'gutter-to-gold'. Int. Dairy J., 18: 695-704

Snedecor, G.M. and Cochran W.G. 1980. Statistical methods, Sixth Edition, lowa State Univ. press, Amer. Lowa, USA.

Stoliar, M. (2009). Whey ingredients in bakery products. U.S. Dairy Export Council, Applications Monographs pp 1-8.

Stampfli, L. and Nersten, B. 1995. Emulsifiers in bread making. Food Chemistry, 52,353-360.

Tolson, D. 2004. Whey protein. Cited by http:// www.bulk nutrition. Com/ a28- wheyprotein.html.

Tripathy, S.; Vijayalakshmi, D. and Jayaprakasha, H.M. 2003. Utilization of whey protein concentrate in ragi (Eleusine coracana) based food products. J. Food Sci. Technol., 40: 157-161

Tseng Y.M.; Lin, S.K.; Hsiao, J.K.; Chen, I.J.; Lee, J.H.; Wu, S.H. and Tsai, L.Y. 2006. Whey protein concentrate promotes the production of glutathione (GSH) by GSH reductase in the PC12 cell line after acute ethanol exposure. Food Chem. Toxicol., 44(4): 574-578.

Valenti, P. and Antonini, G. 2005. Lactoferrin: an important hostdefence against microbial and viral attack. Cellular and Molecular Life Sciences, 62: 2576-2587.

Vani, R.K. and Jayaprakasha, M. 2004. Formulation of instant gulabjamun mix from the admixture of spray dried skim milk powder and whey protein concentrate. J Food Sci. Technol., 41: $244-24$

Vetter J.L. 1984. Whey and whey products in bakery applications. Proc Whey Products Conf, Chicago, Illinois. p 132-135.

Wang and Kinsella, J.E. 1976. Functional Properties of Novel Proteins: Alfalfa Leaf Protein. Journal of Food Science, 41(2): 286-292.

Webb, M.; Naeem, H. and Schmidt, K. 2002. Food protein functionality in a liquid system: A comparison of deamidated wheat protein with dairy and soy proteins. J. Food Sci. 67: 2869-2902.

Wesołowska-Trojanowska, M. and Targoński, Z. 2014. The whey utilization in biotechnological processes. Nauki Inżynierskie i Technologie, 1(12): 102-119.

Zemel, M.B. 2004. Role of calcium and dairy products in energy partitioning and weight management. Am. J. Clin. Nutr., 79: 907-912. 


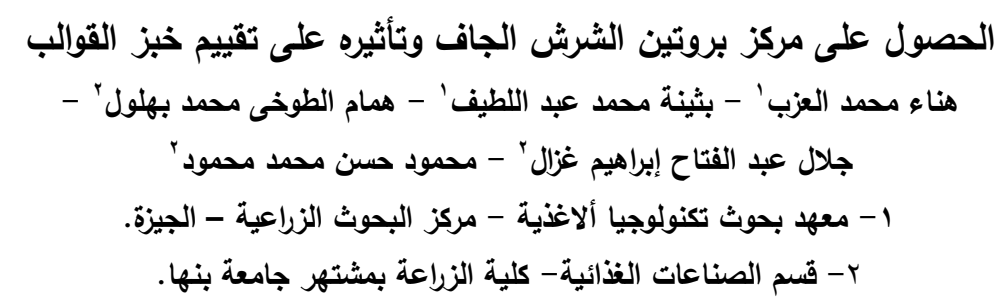

استهدفت الدراسة الحصول بروتين الثرش المركز المجف ودراسة الخصائص الوظيفية والفيزيائية والكيميائية لله تم إضافة برونين الثرش

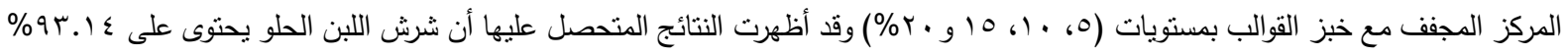

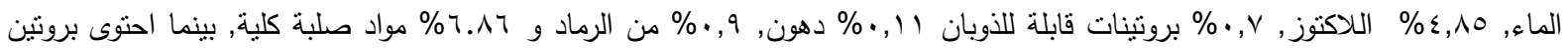

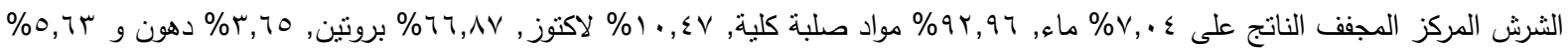

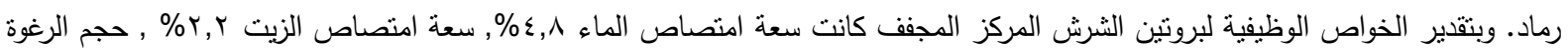

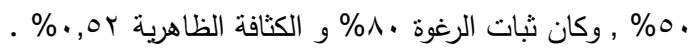
كما لوحظ أن بروتينات شرش اللبن المركز المجفف يحتوى على مستويات مرتفعة من الأحماض الأمينية الأساسية خاصة اللايسين,

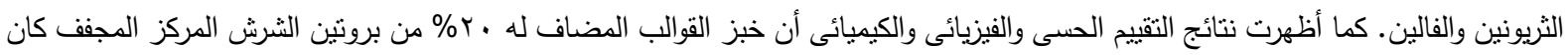

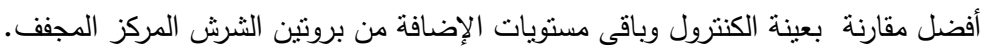

الكلمات الدالة: بروتينات الثرش المركز المجفف - خبز القوالب - الخصائص الفيزيائية والكيميائية - الخصائص الحسية - النشاط المضاد للأكسدة. 